Western University

Scholarship@Western

Obstetrics \& Gynaecology Publications

Obstetrics \& Gynaecology Department

4-1-2005

Effect of serum and cumulus cell expansion on marker gene transcripts in bovine cumulus-oocyte complexes during maturation in vitro.

Michele D Calder

Anita N Caveney

Marc-Andre Sirard

Andrew J Watson

Follow this and additional works at: https://ir.lib.uwo.ca/obsgynpub

Part of the Obstetrics and Gynecology Commons

Citation of this paper:

Calder, Michele D; Caveney, Anita N; Sirard, Marc-Andre; and Watson, Andrew J, "Effect of serum and cumulus cell expansion on marker gene transcripts in bovine cumulus-oocyte complexes during maturation in vitro." (2005). Obstetrics \& Gynaecology

Publications. 42.

https://ir.lib.uwo.ca/obsgynpub/42 


\title{
Effect of serum and cumulus cell expansion on marker gene transcripts in bovine cumulus-oocyte complexes during maturation in vitro
}

\author{
Michele D. Calder, Ph.D., ${ }^{\mathrm{a}}$ Anita N. Caveney, B.Sc., ${ }^{\mathrm{a}}$ Marc-Andre Sirard, Ph.D., D.V.M., ${ }^{\mathrm{b}}$ and \\ Andrew J. Watson, Ph.D. ${ }^{\mathrm{a}}$ \\ ${ }^{a}$ Departments of Obstetrics and Gynecology and Physiology and Pharmacology, University of Western Ontario, London, \\ Ontario, Canada; and ${ }^{\mathrm{b}}$ Centre de Recherche en Biologie de la Reproduction, Departement des Sciences Animales, Université \\ Laval, Quebec, Quebec, Canada
}

\begin{abstract}
Objective: To determine the distribution of transcripts encoding the FSH receptor (FSHr), LH receptor (LHr), connexin 43 (Cx43), cyclooxygenase-2 (COX-2), and prostaglandin $\mathrm{E}_{2}$ receptors 2 and 3 (EP2 and EP3) within bovine cumulus-oocyte complexes (COCs) and denuded oocytes and investigate the influence of gonadotropins, serum, and cumulus cell expansion on the abundance of transcripts encoding these genes.

Design: Prospective controlled animal study.

Setting: University research laboratory.

Patient(s): Animal models for human studies.

Intervention(s): Cumulus-oocyte complexes were treated in culture with serum and gonadotropin-supplemented media to examine the effects to mRNA transcript levels.

Main Outcome Measure(s): Variation in mRNA transcript levels.

Result(s): Luteinizing hormone receptor, FSHr, and EP3 mRNAs were detected in intact COCs and not in cumulus cell-denuded oocytes, whereas $\mathrm{Cx} 43, \mathrm{COX}-2$, and EP2 mRNAs were found in both COCs and oocytes. The relative abundance of marker gene mRNAs did not vary in media containing no additives or FSH alone, independent of whether the media induced cumulus cell expansion. However, the presence of serum in maturation media significantly decreased expression of all mRNAs except LHr.

Conclusion(s): The relative abundance of COC mRNAs is altered by serum in the maturation medium, which may signify long-term consequences for embryonic development. (Fertil Steril ${ }^{\circledR}$ 2005;83(Suppl 1):1077-85. @2005 by American Society for Reproductive Medicine.)
\end{abstract}

Key Words: Oocyte maturation, in vitro fertilization, preimplantation development, gonadotropin receptors, prostaglandin

Progress in the treatment of human infertility is directed toward the development of effective culture conditions for the maturation of human oocytes in vitro (1-4). Despite impressive success in the application of in vitro oocyte maturation methods, there are still concerns regarding their application due to increasing reports highlighting the shortand long-term consequences to development after exposure of mammalian gametes and embryos to culture environments. Most of our knowledge in this area has been gained from studies applied to animal species, and it is still common to supplement oocyte maturation media with serum and gonadotropins. Although at least $80 \%$ of bovine oocytes cultured without hormones undergo spontaneous nuclear

Received May 4, 2004; revised and accepted August 23, 2004

Supported by the Natural Sciences and Engineering Research Council of Canada, a Paton-Collins Women's Health postdoctoral fellowship, and a Premier's Research Excellence Award from the Ontario Provincial Government.

Reprint requests: Michele D. Calder, Ph.D., Departments of Obstetrics and Gynecology and Physiology and Pharmacology, Child Health Research Institute, 5th floor, Victoria Research Laboratories, 800 Commissioner's Rd. E., London, Ontario, Canada, N6A 4 G5 (FAX: 519-6858186; E-mail: Michele.Calder@fmd.uwo.ca). maturation, gonadotropins are often added to maturation media to induce cytoplasmic maturation and cumulus expansion and to improve embryonic development (5). Follicle stimulating hormone (FSH) induces expansion of mouse cumulus-oocyte complexes (COCs) in vitro (6) and may improve bovine maturation, fertilization, and cleavage $(5,7)$. Luteinizing hormone (LH) has beneficial effects on bovine oocyte maturation (8). For gonadotropins to act on the COC in vitro, both $\mathrm{FSH}$ and $\mathrm{LH}$ receptor ( $\mathrm{FSHr}$ and $\mathrm{LHr}$ ) mRNAs and proteins must be expressed. FSHr mRNA has been detected in the bovine COC $(9,10)$. Recently, LHr mRNA was detected by the application of reverse transcriptionpolymerase chain reaction (RT-PCR) methods to measure mRNA transcript levels in bovine COCs during in vitro maturation (10).

Other potential marker genes have important roles during in vitro oocyte growth or maturation. The connexin gene family encodes proteins that form gap junctions important for cell-to-cell communication and coordinate responses (11). Connexin $43(\mathrm{Cx} 43)$ mRNA and protein is present in the bovine COC during in vitro maturation (IVM) $(10,12$, 13). Gap junctions may have an important role during bovine 
oocyte IVM as the blocking of gap junction signaling or the reduction of $\mathrm{Cx} 43$ protein resulted in impaired oocyte maturation (14).

Cyclooxygenase-2 (COX-2) is an important enzyme controlling prostaglandin synthesis (15). Prostaglandin $\mathrm{E}_{2}$ $\left(\mathrm{PGE}_{2}\right)$ stimulates cumulus cell expansion in rodents and cattle $(16,17)$. In addition, murine lines that carry functional deletions for COX-2 and the prostaglandin receptor 2 (EP2) display defects in ovulation and fertilization $(18,19)$. The mRNAs of COX-2 and two PGE $_{2}$ receptors, EP2 and EP3, are expressed in bovine COCs in vitro (17), which suggests that they may have an important role in oocyte maturation.

Despite improvements in oocyte culture, at best only $30 \%-35 \%$ of immature mammalian COCs eventually develop to the blastocyst stage in vitro after oocyte maturation, insemination, and embryo culture (20). Whether the oocyte has been matured in vivo or in vitro has a significant influence on the number of embryos that develop to the blastocyst stage $(21,22)$. This suggests that there are still improvements to be made in enhancing oocyte competence during IVM. Although culture medium composition is documented to affect embryo mRNA abundance (13), there is only limited information regarding changes in mRNA abundance in the COC during IVM (23-29), especially under varying hormone and serum regimes. If oocyte IVM is to be optimized for humans or any other mammalian species, it will be necessary to define the influences of medium constituents on oocyte mRNA patterns. This study begins that process by focusing on defining the role of serum and gonadotropin treatment on the expression of gonadotropin and prostaglandin receptor transcripts during bovine oocyte IVM.

\section{MATERIALS AND METHODS Ovary Collection and Isolation of COCs}

Bovine COCs were isolated by follicular aspiration using an 18-gauge needle connected to a vacuum system from slaughterhouse ovaries provided by the Department of Biomedical Sciences, University of Guelph (Guelph, ON, Canada). Serum-free TCM-199 (Gibco BRL, Burlington, ON, Canada) buffered with HEPES and bicarbonate and containing 50 $\mathrm{IU} / \mathrm{mL}$ heparin (Leo Pharma, Ajax, ON, Canada) was used for washing COCs. Pools of 50-60 COCs were matured in vitro in $0.5 \mathrm{~mL}$ TCM-199 containing bicarbonate and pyruvate in 4-well plates (NUNC, Roskilde, Denmark) at $38.5^{\circ} \mathrm{C}$ in a $5 \% \mathrm{CO}_{2}$ in air atmosphere.

\section{Detection of Marker Gene mRNAs in COCs and Denuded Oocytes}

In the first experiment, the presence of transcripts encoding FSHr, LHr, Cx43, COX-2, and EP2 and EP3 mRNAs was determined in intact COCs and denuded oocytes. Cumulusoocyte complexes $(\mathrm{n}=50)$ were harvested at 0,6 , or 24 hours of culture in maturation medium. Oocytes were obtained after 0,6 , and 24 hours of IVM by vortexing COCs for several minutes to remove the majority of the cumulus investment. Oocytes were then washed twice and placed into warmed $1 \%$ pronase (Proteinase E, Sigma-Aldrich, Oakville, Ontario, Canada) solution in TCM-199 to dissolve the zona pellucida. Zona-free oocytes were then washed two to three more times with a change in pipettes. Samples were then frozen in liquid nitrogen before storage at $-70^{\circ} \mathrm{C}$.

\section{Effect of Maturation Media Composition on Marker Gene Transcript Levels}

Patterns of COC marker gene transcript levels were examined after culture in hormone- and/or serum-supplemented TCM-199 medium containing bicarbonate and pyruvate. The groups tested were [1] no hormone (no H); [2] $100 \mathrm{ng} / \mathrm{mL}$ (porcine) pFSH (100); [3] $100 \mathrm{ng} / \mathrm{mL}$ pFSH plus $10 \%$ serum (newborn calf serum, Gibco BRL) (100s); [4] 1,000 ng/mL pFSH $(1,000)$; or [5] the positive control containing 1,000 $\mathrm{ng} / \mathrm{mL} \mathrm{pFSH}$, LH (5 $\mu \mathrm{g} / \mathrm{mL}$ porcine LH, Lutropin-V, Bioniche Animal Health, Belleville, Ontario, Canada), $\mathrm{E}_{2}-$ $17 \beta\left(1 \mu \mathrm{g} / \mathrm{mL} \mathrm{E}_{2}-17 \beta\right.$, Sigma-Aldrich, Oakville, ON, Canada), and $10 \%$ serum (FSH lit Estradiol Serum [FLES]). Aliquots of COCs $(n=50)$ were collected after 6 or 24 hours of IVM. The COCs were placed into $0.5-\mathrm{mL}$ microcentrifuge tubes, and excess medium was removed after brief centrifugation. Samples were then frozen in liquid nitrogen before storage at $-70^{\circ} \mathrm{C}$. The experiment was replicated four times.

\section{Isolation of RNA, RT, and PCRs}

Total RNA from oocytes and COCs was extracted with 12-24 $\mu \mathrm{g}$ E. coli rRNA (Roche Molecular Biochemicals, Laval, QC, Canada) as a carrier by using a standard phenol/ chloroform extraction method (30). RNA samples were reverse transcribed with oligo-(dT) ${ }_{12-18}$ primer (Gibco BRL) and Superscript (Gibco BRL) as described elsewhere (17, 31). RNA from positive control bovine tissues (liver for $\beta$-actin, ovary for FSHr, corpus luteum for $\mathrm{LHr}$ and EP3, kidney for COX-2 and EP2, and brain for $\mathrm{Cx} 43$ ) was extracted using a standard laboratory phenol/chloroform technique (32), and 1-2.5 $\mu \mathrm{g}$ RNA was reverse transcribed as above. Polymerase chain reactions (PCR) were performed with 10× PE Gold buffer (Perkin-Elmer, Canada Ltd., Mississauga, ON, Canada) with 1.25-2 $\mathrm{mM} \mathrm{MgCl}_{2}, 1 \mu \mathrm{M}$ (2 $\mu \mathrm{M}$ for actin, $0.1 \mu \mathrm{M}$ for $\mathrm{Cx} 43$ ) primers, $200 \mu \mathrm{M}$ dNTPs (Gibco-BRL), and 1 unit AmpliTaq Gold DNA Polymerase (Perkin-Elmer). All primer sequences were reported previously $(9,10,17,31)$ and were synthesized by Gibco BRL. The identity of FSHr, LHr, Cx43, EP2, EP3, and COX-2 PCR products was confirmed by dyedeoxysequencing (Robarts Research Institute, London, ON, Canada). The basic PCR amplification program consisted of a soak at $95^{\circ} \mathrm{C}$ for 10 minutes, followed by a cycle program of $95^{\circ} \mathrm{C}$ for 1 minute, gene specific annealing temperature for 30 seconds and $72^{\circ} \mathrm{C}$ for 1 minute, and a final extension at $72^{\circ} \mathrm{C}$ for 10 minutes. In each sample, $\beta$-actin expression was examined as a positive control to 
ensure that RNA extraction was efficient, and because these primers are intron spanning, they were used to detect possible genomic contamination (243-bp vs. 408-bp product). No genomic contamination was detected. PCR reactions were conducted in a Perkin-Elmer GeneAmp 2400 thermocycler (PE Applied Biosystems, Mississauga, ON, Canada) for 45 cycles to compensate for lower RNA abundance in oocytes compared with COC samples. Twenty microliters of product was resolved on a $2 \%$ agarose gel containing ethidium bromide and a GeneRuler 100 bp DNA ladder (MBI Fermentas, Flamborough, ON, Canada). Photographs were taken with a UV camera system (Amersham Pharmacia Biotech, Baie d'Urfé, QC, Canada).

In the second experiment, marker gene expression was subjected to semiquantitative RT-PCR analysis. RNA samples were reverse transcribed as described above with $0.1 \mathrm{pg}$ rabbit globin mRNA (Gibco BRL) added per COC equivalent just before RT $(17,31)$. Two microliters of cDNA (two COC equivalents) was added to each $50 \mu \mathrm{L}$ PCR reaction. For amplification, 37 cycles were used for FSHr, LHr, and $\mathrm{EP} 2$; 38 cycles for COX-2 and EP3; 39 cycles for $\mathrm{Cx} 43$; and 30 cycles for the $\alpha$-globin standard. Twenty microliters of product was resolved on a $2 \%$ agarose gel containing ethidium bromide and a 100-bp DNA ladder (MBI Fermentas). Image analysis and quantification was conducted with the ImageMaster VDS program (Amersham Pharmacia Biotech). Bands were quantified by comparing the ratio of band intensity to the $\alpha$-globin standard $(17,31)$.

\section{Statistical Analyses}

Multiple analyses of variance were performed using the Practical Statistics program (Canadian Academic Technology, West Flamborough, ON, Canada), with main effects of maturation time (6 hours or 24 hours) and type of media. Where significant main effects or interactions existed, Duncan's mean separation procedures were performed to detect differences.

\section{RESULTS \\ Detection of Marker Gene mRNAs in COCs and Denuded Oocytes}

Transcripts encoding LHr, FSHr, and EP3 mRNAs were detected only in intact COCs and not in denuded oocytes (Fig. 1). COX-2, EP2, and Cx43 mRNAs were observed in both intact COCs and denuded oocytes.

\section{Cumulus Expansion and Expression of Marker Genes at 6 and 24 Hours of IVM in Media With Different Additives}

Full cumulus expansion occurs after incubation of COCs in maturation medium containing $1,000 \mathrm{ng} / \mathrm{mL} \mathrm{pFSH}$ in serumfree medium and in the positive control containing $\mathrm{pFSH}$, $\mathrm{pLH}, \mathrm{E}_{2}$, and $10 \%$ serum (10). Little expansion occurs after maturation in medium containing no hormones or only 100
ng/mL FSH. A moderate amount of expansion occurs when COCs are incubated in TCM-199 containing $100 \mathrm{ng} / \mathrm{mL}$ pFSH and $10 \%$ serum (10).

The FSHr primers amplify a full-length and an exon 9 -deleted FSHr isoform $(9,10)$. There was a significant interaction between media and time on the relative abundance of the full-length FSHr mRNA $(P<.04$; Fig. 2A). Full-length FSHr mRNA was lower in FLES at 24 hours than in all other groups except 100s at 24 hours (all $P<.05$ ) and was lower in 100s at 24 hours than in 100 at 6 hours $(P<.01)$ and 100 at 24 hours $(P<.05)$. There was a significant interaction between media and time on the relative abundance of transcripts encoding the exon 9-deleted FSHr isoform $(P<.01$; Fig. 2B). Serum-containing groups, FLES and 100s, had lower FSHr mRNA levels at both 6 and 24 hours than serum-free groups (all $P<.05$ ). The abundance of the exon 9-deleted FSHr isoform mRNA was lower at the 6-hour time point in no $\mathrm{H}, 100$, and 1,000 than at their corresponding 24-hour time points (all $P<.05$ ).

Abundance of LHr mRNA was lower in COCs cultured for 6 hours than for 24 hours $(P<.005$; Fig. 2C). There was no significant effect of media or interaction. The effect of medium composition on the COX-2 mRNA relative abundance was highly significant $(P<.00001$; Fig. 3A). COX-2 mRNA was higher in no $\mathrm{H}, 100$, and 1,000 (all $P<.01$ ) than in both groups containing serum, 100s and FLES. COX-2 transcript levels were also higher in no $\mathrm{H}$ and 100 than in 1,000 (both $P<.05$ ). There was no difference in relative abundance of COX-2 mRNA between 6 and 24 hours of maturation $(P>.64)$ and no significant interaction.

The relative abundance of EP2 mRNA was affected by maturation medium $(P<.003$; Fig. 3B). EP2 mRNA was higher in the no $\mathrm{H}(P<.05), 100(P<.05)$, and 1,000 groups $(P<.01)$ than in both the FLES and 100s groups. There was no difference in the relative abundance of EP2 mRNA between the 6-hour and 24-hour maturation times $(P>.13)$ and no interaction.

EP3 mRNA relative abundance was affected by maturation medium composition $(P<.006$; Fig. 3C). Expression was higher in the no $\mathrm{H}(P<.01), 100(P<.05)$, and 1,000 groups $(P<.05)$ than in the FLES group. The relative abundance of EP3 transcripts was not different in the 100s group compared with other groups. Across media, the relative abundance of EP3 mRNA was higher at 24 hours than at 6 hours $(P<.005)$, but there was no interaction between media and time.

The relative abundance of $\mathrm{Cx} 43$ mRNAs was affected by maturation medium $(P<.001$; Fig. 3D). Cx43 mRNA was lower in the 100s than in the 100 and 1,000 (both $P<.01$ ) and no $\mathrm{H}$ groups $(P<.05)$, while the FLES group was lower than the 1,000 group $(P<.05)$. There was a tendency for $\mathrm{Cx} 43$ mRNA abundance to increase from 6 to 24 hours $(P>.06)$, but no significant interaction was observed. 
Detection of marker gene mRNAs in cumulus-oocyte-complexes (COCs) and denuded oocytes, representative reverse transcriptase-polymerase chain reaction figures. The lanes are COC; ooc (denuded oocyte); - (negative control lane); + (positive tissue control); and MW (100-bp marker lane).
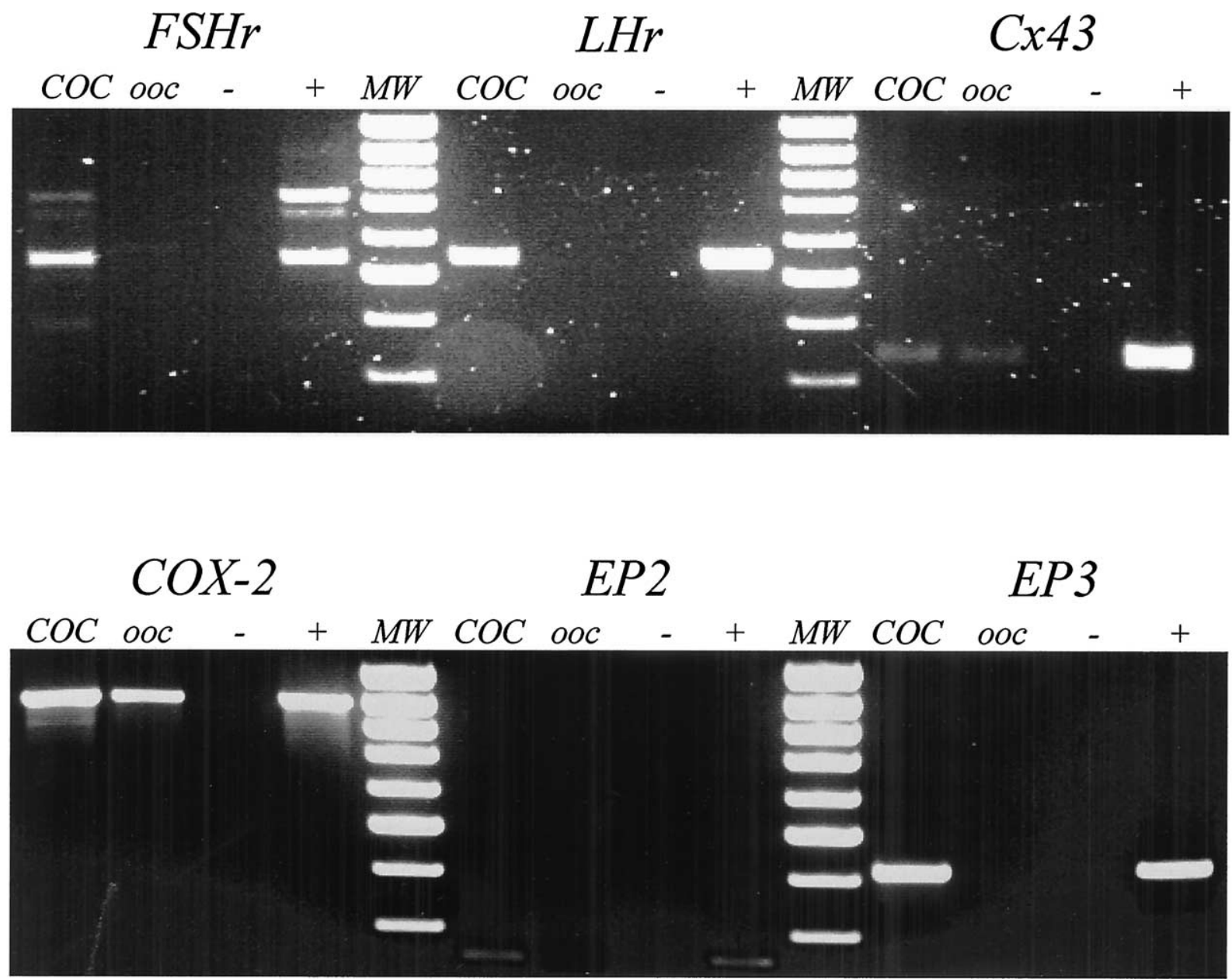

Calder. Oocyte maturation in vitro. Fertil Steril 2005.

\section{DISCUSSION}

In the current studies, isoforms of FSHr mRNA were expressed only in intact bovine COCs and not in denuded oocytes, which agrees with an earlier study (9). These data lend further support to the fact that in mice FSH stimulates meiosis only when cumulus is directly attached to mouse oocytes (33). However, the presence of FSHr mRNA and the protein and calcium response to FSH has been reported in human oocytes (34). The full-length FSHr isoform remained highly expressed at 24 hours of maturation in COCs when they were cultured in serum-free media (no $\mathrm{H}$ and 100), even when the cumulus was fully expanded, as occurs in the 1,000 FSH treatment. This suggests that FSH did not downregulate expression of its receptor mRNA in the expanded COCs. These data correlate with the lack of reduction in FSHr mRNA in granulosa cells cultured with FSH or pregnant mare's serum gonadotropin (PMSG) $(35,36)$. The abundance of full-length FSHr isoform mRNA was lowest at 24 hours in maturation medium containing gonadotropins, $\mathrm{E}_{2}$, and serum (FLES) and tended to be lower in 100s than serum-free media. Although the role of the truncated isoform is unclear, its abundance was also lower in serum-containing media at both 6 and 24 hours than in serum-free media. As radiolabeled FSH binding declined in rat $\mathrm{COCs}$ cultured in media containing serum but without hormones (37), it seems likely that serum exposure causes a down-regulation in FSHr mRNA expression.

Luteinizing hormone receptor mRNA was detectable only in COCs and not in denuded oocytes. These data agree with earlier studies documenting a lack of expression of $\mathrm{LHr}$ mRNA in bovine oocytes $(9,24)$ and a lack of LHr mRNA, protein, and response to hCG in human oocytes (34). The abundance of LHr mRNA was affected only by maturation 
Relative abundance of high- follicle stimulating hormone receptor (FSHr) isoform mRNA, low-FSHr isoform (exon 9) mRNA, and luteinizing hormone receptor (LHr) mRNA in bovine cumulus-oocyte-complexes (COCs) cultured in one of five oocyte maturation media treatments. Pink bars show the relative abundance in medium with no added hormones (no H) at 6 and 24 hours. Yellow bars show the relative abundance in 100 $\mathrm{ng} / \mathrm{mL} \mathrm{pFSH}(100)$ at 6 and 24 hours. Green bars show the relative abundance in $100 \mathrm{ng} / \mathrm{mL} \mathrm{pFSH}$ and serum (100s) at 6 and 24 hours. Blue bars show the relative abundance in $1,000 \mathrm{ng} / \mathrm{mL} \mathrm{pFSH}(1,000)$ at 6 and 24 hours. Orange bars show the relative abundance in medium containing standard concentrations of $\mathrm{pFSH}, \mathrm{pLH}, \mathrm{E}_{2}$, and serum (FLES) at 6 and 24 hours. Values are mean $\pm \mathrm{SE}(\mathrm{n}=4$ replicates). (A) For levels of full-length FSHr transcripts, the interaction of medium composition and time was significant: $P<.04$. The superscript "abc" shows bars with no superscripts in common that are different at $P<.05$. (B) For levels of exon 9-deleted FSHr transcripts, the interaction of medium composition and time was significant: $P<.01$. The superscript "abcd" shows bars with no superscripts in common that are different at $P<.05$. (C) For levels of LHr, the superscript "xy" denotes overall differences between 6 and 24 hours at $P<.05$.

\section{A $\quad$ Full Length FSHr}

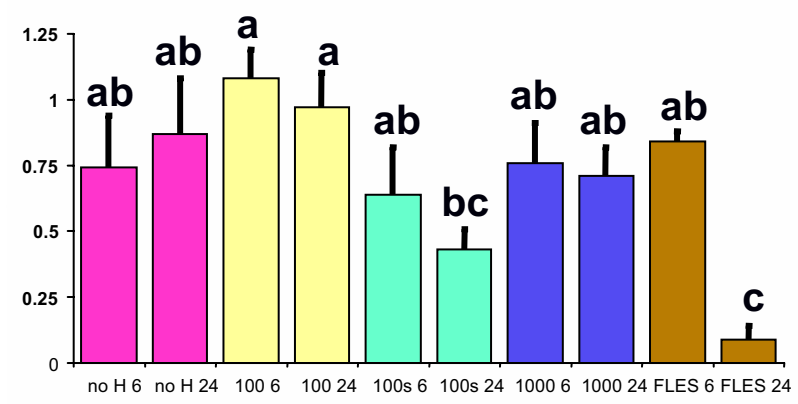

B Exon 9 Deleted FSHr

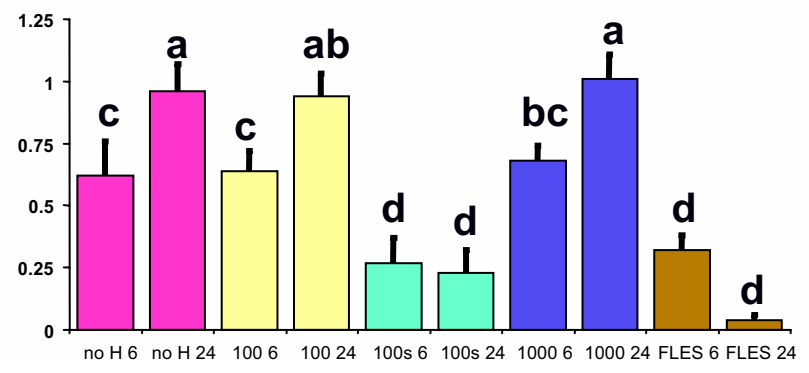

Calder. Oocyte maturation in vitro. Fertil Steril 2005.

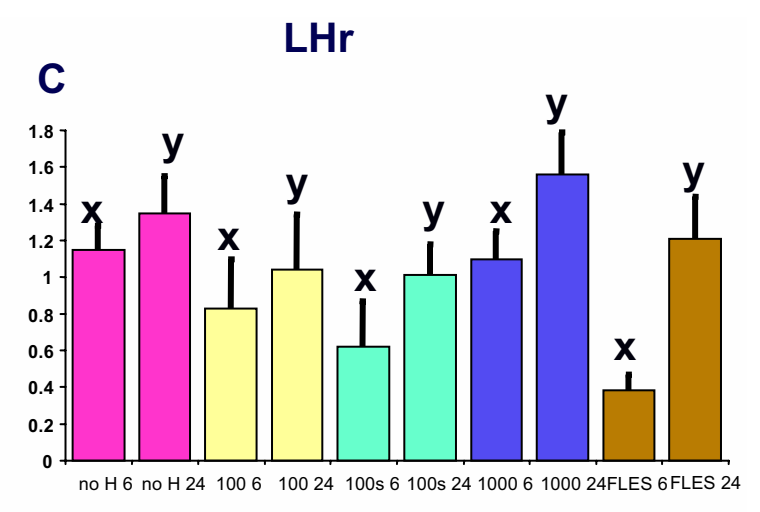

LHr time and not by medium composition. In the current experiment, LHr mRNA abundance was higher at 24 hours of maturation than at 6 hours. It has been reported that mouse germinal vesicle oocytes suppress expression of LHr mRNA in both cumulus and granulosa but that mature oocytes are less effective in suppressing granulosa LHr mRNA (38). Although culture medium composition does not affect the levels of LHr mRNA in bovine COCs, the increase of $\mathrm{LHr}$ mRNA in cumulus cells during culture may be associated with the progression of oocyte maturation.

COX-2 mRNA was detected in both denuded oocytes and in intact bovine COCs. COX-2 mRNA has been detected previously in mouse cumulus cells $(19,39)$. The absence of COX-2 mRNA expression in oocytes as well as in cumulus cells could contribute to the defects in cumulus cell expansion, ovulation, and fertilization observed in the COX-2 mouse null mutant (18). There was no effect of time on the abundance of COX-2 mRNA in bovine COCs.

Continued high abundance of COX-2 mRNAs in bovine COCs cultured in serum-free media at 24 hours is consistent with high COX-2 mRNA and protein expression in bovine granulosa cells $(40,41)$ and in mouse cumulus cells in the late preovulatory period $(19,39)$. The effect of media on COX-2 mRNA relative abundance was highly significant. 
Relative abundance of COX-2, EP2, EP3, and Cx43 mRNAs in bovine cumulus-oocyte-complexes (COCs) cultured in one of five oocyte maturation media treatments. Pink bars show the relative abundance in no $\mathrm{H}$ at 6 and 24 hours. Yellow bars show the relative abundance in 100 at 6 and 24 hours. Green bars show the relative abundance in 100s at 6 and 24 hours. Blue bars show the relative abundance in 1,000 at 6 and 24 hours. Orange bars show the relative abundance in FLES at 6 and 24 hours. Values are mean $\pm S E(n=4$ replicates). (A) For COX-2 transcripts, the superscript "abc" denotes differences among media at $P<.05$. (B) For EP2 transcripts, the superscript "ab" denotes differences among media at $P<.05$. (C) For EP3 transcripts, "ab" denotes differences in media; at $P<.05$, and the superscript "xy" denotes overall differences between times at $P<.05$. (D) For Cx43 transcripts, the superscript "abc" denotes differences among media at $P<.05$.
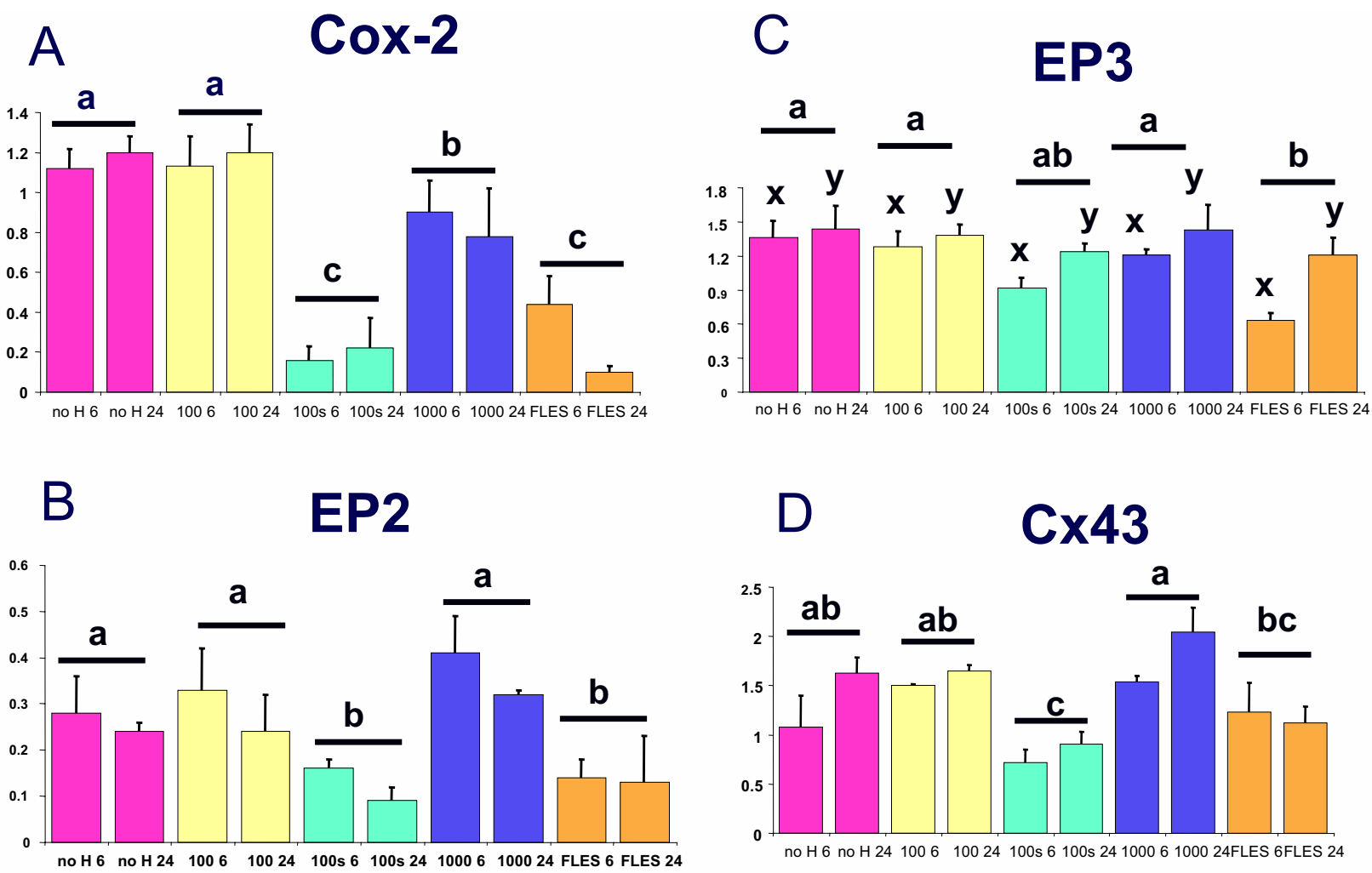

Calder. Oocyte maturation in vitro. Fertil Steril 2005.

The serum-free treatment displayed a higher relative abundance of COX-2 mRNA than the serum-containing media treatments. Although serum induces expression of COX-2 in a number of cell systems (15), low COX-2 mRNA expression in COCs cultured with media containing serum is consistent with decreased expression of COX-2 mRNA in human granulosa cells cultured in serum-containing medium (42). In bovine preovulatory follicles, COX-2 mRNA and protein are not expressed until several hours after the gonadotropin surge (41), yet bovine COCs are usually recovered from smaller follicles. Elsewhere, we have shown that COX-2 mRNA was expressed at low levels in freshly collected bovine COCs and increased by 6 hours of maturation (17). In the current experiments, COX-2 mRNA was likely induced in all treatments by removal of the COCs from the follicle and initiation of in vitro oocyte maturation.
By contrast, mouse COCs are obtained from PMSGstimulated preovulatory follicles, which may have higher basal COX-2 mRNA expression. In mouse COCs, expression of COX-2 mRNA is stimulated by FSH but not by LH or hormone-free medium (39). Cumulus cell expansion due to COX-2- $\mathrm{PGE}_{2}$-EP2 and FSH pathways may be at least partially independent as cumulus cell expansion still occurs in mouse EP2-knockout COCs in response to FSH but not to $\mathrm{PGE}_{2}$ (19). Moreover, $\mathrm{PGE}_{2}$-stimulated bovine cumulus expansion requires the presence of serum in the medium (17), whereas FSH-stimulated cumulus expansion does not require serum (10). Perhaps the relative abundance of COX-2 mRNA is highest in bovine COCs cultured without hormones or with low FSH because these COCs are unable to fully initiate cumulus cell expansion in serum-free medium without sufficient FSH stimulation. 
EP2 mRNA was detected in both denuded bovine oocytes and in COCs. EP2 mRNAs were previously detected in mouse cumulus cells (19) and bovine COCs (17). The presence of EP2 mRNA expression in oocytes as well as cumulus cells could contribute to the defects in cumulus cell expansion, ovulation, and fertilization observed in the mouse EP2 null mutant (19). Maturation medium composition had a striking effect on COC EP2 mRNA relative abundance. The presence of serum in the maturation media significantly suppressed expression of EP2 mRNA compared with the serum-free treatments. This was consistent with decreased expression of EP2 mRNA in human granulosa cells cultured in serum-containing medium compared with freshly isolated granulosa cells (43).

EP3 mRNA was detected only in intact COCs and not in denuded oocytes. In the current experiments, across media, there was an increased abundance of EP3 mRNA at 24 hours compared with 6 hours. This agrees with the results of a previous experiment, where expression of EP3 mRNA in bovine COCs increased from 6 to 12 hours and then remained stable up to 24 hours (17). Because EP3 mRNA is expressed in bovine corpora lutea and expression increased in granulosa cells during culture (40), it is likely that the increasing EP3 mRNA abundance in bovine COCs is related to increasing luteinization of the cumulus cells. Maturation media also had a significant effect on the abundance of EP3 mRNA. The amount of EP3 mRNA was lowest in COCs cultured in media containing gonadotropins, $\mathrm{E}_{2}$, and serum; it was intermediate in 100s, while serum-free treatments had the highest EP3 abundance. Although EP3 mRNA expression increased during culture of granulosa cells in medium containing serum (40), it would appear from the current study that culture increases while serum decreases the relative abundance of EP3 mRNA.

Cx43 mRNA was detected in both denuded bovine oocytes and in COCs. Cx43 mRNA and protein has previously been detected in bovine cumulus cells $(12,14)$, but the protein was not detected in bovine oocytes in two studies $(44,45)$, while $\mathrm{Cx} 43 \mathrm{mRNA}$ has been detected in bovine oocytes during IVM (13). Recently, Cx43 mRNA and protein have been detected and localized to gap junctions in rat oocytes (46). In the current experiments, Cx43 mRNA relative abundance was affected by maturation medium. The abundance of $\mathrm{Cx} 43 \mathrm{mRNA}$ was lower in the 100s treatment than all other media treatments except FLES, and FLES displayed lower Cx43 mRNA levels than the 1,000 FSH treatment. Serum has a suppressive effect on blastocyst $\mathrm{Cx} 43$ mRNA expression (13), and this effect is now known to occur even during oocyte maturation. In rat COCs during maturation, a reduction in gap junctions was proportional to the amount of cumulus cell expansion (47). However, in the current study, the abundance of Cx43 mRNA was greater, although cumulus cell expansion was more extensive in the $1,000 \mathrm{FSH}$ treatment over that observed in the 100s group. This suggests that if Cx43 mRNA is reduced during maturation, it is affected more by serum rather than by cumulus cell expansion. The lack of effect of time on Cx 43 mRNA abundance was not unanticipated because, although $\mathrm{Cx} 43$ gap junctions decrease between the bovine cumulus cell and oocyte by 6 hours of maturation, there are still numerous functional gap junctions in cumulus cells at 24 hours of maturation (12). Despite unchanged abundance of $\mathrm{Cx} 43$ mRNA and protein in rat oocytes during maturation, the phosphorylation status of the Cx43 protein changed (46), which may have affected gap junction function. Overall, these factors may limit the usefulness of $\mathrm{Cx} 43$ mRNA as a marker gene.

One of the principal findings of this study is that there were significant differences in transcript levels between serum-free and serum-containing oocyte maturation treatment groups. Certain serum components enter the follicle during the late preovulatory period and contribute to cumulus cell expansion (48). Although serum is a component of many oocyte and embryo culture systems, it has been linked to alterations in blastocyst development and development of large offspring syndrome in cattle and sheep $(21,49)$. The presence of serum in embryo culture media decreased expression of several embryo marker genes in some studies (13) and increased expression of others (49). That EP2 and COX-2 mRNAs, which are normally highly expressed in cumulus cells at the late preovulatory stage in vivo (19), were significantly affected when COCs were cultured in serum-supplemented medium, suggests that these mRNAs may be useful marker genes for assessing oocyte maturation.

Cumulus cell expansion is often considered as a sign of cytoplasmic maturation; however, in the current studies, expression of marker genes was similar in COCs cultured in serum-free media whether or not cumulus cell expansion was induced. Only for COX-2 mRNA was expression lower in COCs undergoing expansion $(1,000 \mathrm{ng} / \mathrm{mL} \mathrm{FSH}) \mathrm{com}-$ pared with nonexpanding COCs (no H and $100 \mathrm{ng} / \mathrm{mL} \mathrm{FSH}$ ), which may suggest that moderate COX-2 mRNA expression is the most appropriate response to IVM. These findings are of importance and are relevant to the application of in vitro oocyte maturation methods in all species, including the human, as serum is a common additive of oocyte maturation media. The inclusion of serum in culture media, even as early as the oocyte maturation stage, may adversely impact embryo development by altering the abundance of key cumulus and oocyte mRNAs (29). We would therefore suggest that progress in this area be directed toward the characterization of effective serum-free media for oocyte maturation in all mammalian species.

Acknowledgments: The authors thank Lisa Barcroft, David Natale, and the Department of Biomedical Sciences, University of Guelph (Guelph, ON), for assisting with ovary and oocyte collections. We would like to thank Dr. Tom Kennedy for assisting with statistical analysis and Dr. Gerry Kidder for Cx43 primers.

\section{REFERENCES}

1. Liu J, Lu G, Quian Y, Mao Y, Ding W. Pregnancies and births achieved from in vitro matured oocytes retrieved from poor responders under- 
going stimulation in in vitro fertilization cycles. Fertil Steril 2003;80:447-9.

2. Wang WH, Gill J. In vitro maturation and in vitro fertilization of human oocytes. Meth Mol Biol 2004;253:235-54.

3. Chian RC, Buckett WM, Tan SL. In-vitro maturation of human oocytes. Reprod Biomed Online 2004;8:148-66.

4. Check JH. In vitro maturation of oocytes. Fertil Steril 2004;81:479-80.

5. Sirard M-A, Parrish JJ, Ware CB, Leibfried-Rutledge ML, First NL. The culture of bovine oocytes to obtain developmentally competent embryos. Biol Reprod 1988;39:546.

6. Eppig JJ. Gonadotropin stimulation of the expansion of cumulus oophori isolated from mice: general conditions for expansion in vitro. $\mathbf{J}$ Exp Zool 1979;208:111-20.

7. Izadayar F, Zeinstra E, Bevers MM. Follicle-stimulating hormone and growth hormone act differently on nuclear maturation while both enhance developmental competence of in vitro matured bovine oocytes. Mol Reprod Dev 1998;51:339-45.

8. Zuelke KA, Brackett B. Luteinizing hormone-enhanced in vitro maturation of bovine oocytes with and without protein supplementation. Biol Reprod 1990;43:784-87.

9. van Tol HTA, Eijk MJT, Mummery CL, van den Hurk R, Bevers MM. Influence of FSH and hCG on the resumption of meiosis of bovine oocytes surrounded by cumulus cells connected to membrane granulosa. Mol Reprod Dev 1996;45:218-24.

10. Calder MD, Caveney AN, Smith LC, Watson AJ. Responsiveness of bovine cumulus-oocyte-complexes (COC) to porcine and recombinant human $\mathrm{FSH}$, and the effect of COC quality on gonadotropin receptor and $\mathrm{Cx} 43$ marker gene mRNAs during maturation in vitro. Reprod Biol Endocrinol 2003;1:14-25.

11. Bruzzone R, White TW, Paul DL. Connections with connexins: the molecular basis of direct intercellular signaling. Eur J Biochem 1996; 238:1-27.

12. Sutovsky P, Flechon JE, Flechon B, Motlik J, Peynot N, Chesne P, et al. Dynamic changes of gap junctions and cytoskeleton during the in vitro culture of bovine cumulus oocyte complexes. Biol Reprod 1993; 49:1277-87.

13. Wrenzycki C, Herrmann D, Carnwath JW, Niemann H. Alterations in the relative abundance of gene transcripts in preimplantation bovine embryos cultured in medium supplemented with either serum or PVA. Mol Reprod Dev 1999;53:8-18.

14. Vozzi C, Formenton A, Chanson A, Senn A, Sahli R, Shaw P, et al. Involvement of connexin 43 in meiotic maturation of bovine oocytes. Reproduction 2001;122:619-28.

15. Hershman HR. Prostaglandin synthase 2. Biochim Biophys Acta 1996; 1299:125-40.

16. Eppig JJ. Prostaglandin E2 stimulates cumulus expansion and hyaluronic acid synthesis by cumuli oophori isolated from mice. Biol Reprod 1981;25:191-5.

17. Calder MD, Caveney AN, Westhusin MH, Watson AJ. Cyclooxygenase-2 and prostaglandin $\mathrm{E}_{2}$ receptor messenger RNAs are affected by bovine oocyte maturation time and cumulus-oocyte complex quality, and $\mathrm{PGE}_{2}$ induces moderate expansion of the bovine cumulus in vitro. Biol Reprod 2001;65:135-40.

18. Lim H, Paria BC, Das SK, Dinchuk JE, Langenbach R, Trzaskos JM, et al. Multiple female reproductive failures in cyclooxygenase 2-deficient mice. Cell 1997;91:197-208.

19. Hizaki H, Segi E, Sugimoto Y, Hirose M, Saji T, Ushikubi F, et al. Abortive expansion of the cumulus and impaired fertility in mice lacking the prostaglandin E receptor sub-type EP2. Proc Natl Acad Sci 1999;96:10501-506.

20. Keskintepe L, Burnley CA, Brackett BG. Production of viable bovine blastocysts in defined in vitro conditions. Biol Reprod 1995;52:1410-7.

21. Thompson JG, Gardner DK, Pugh PA, McMillan WH, Tervit HR. Lamb birth weight is affected by culture system utilized during in vitro pre-elongation development of ovine embryos. Biol Reprod 1995;53: 1385-91.

22. Rizos D, Ward F, Duffy P, Boland MP, Lonergan P. Consequences of bovine oocyte maturation, fertilization or early embryo development in vitro versus in vivo: implications for blastocyst yield and blastocyst quality. Mol Reprod Dev 2002;61:234-48.

23. Coenen K, Massicotte L, Sirard M-A. Study of newly synthesized proteins during bovine oocyte maturation in vitro using image analysis of two-dimensional gel electrophoresis. Mol Reprod Dev 2004;67:313-22.

24. Robert C, Gagne D, Lussier JG, Bousquet D, Barnes FL, Sirard M-A. Presence of LH receptor mRNA in granulosa cells as a potential marker of oocyte developmental competence and characterization of the bovine splicing isoforms. Reproduction 2003;125:437-46.

25. Robert C, Hue I, McGraw S, Gagne D, Sirard M-A. Quantification of cyclin B1 and p34(cdc2) in bovine cumulus-oocyte complexes and expression mapping of genes involved in the cell cycle by complementary DNA macroarrays. Biol Reprod 2002;67:1456-64.

26. Lonergan P, Rizos D, Gutierrez-Adan A, Fair T, Boland MP. Oocyte and embryo quality: effects of origin, culture conditions and gene expression patterns. Reprod Domest Anim 2003;38:259-67.

27. Lonergan P, Rizos D, Gutierrez-Adan A, Fair T, Boland MP. Effect of culture environment on embryo quality and gene expression-experience from animal studies. Reprod Biomed Online 2003;7:657-63.

28. Knijn HM, Wrenzycki C, Hendriksen PJ, Vos PL, Herrmann D, van der Weijden GC, et al. Effects of oocyte maturation regimen on the relative abundance of gene transcripts in bovine blastocysts derived in vitro or in vivo. Reproduction 2002;124:365-75.

29. Watson AJ, de Sousa P, Caveney A, Barcroft LC, Natale D, Urquhart $\mathrm{J}$, et al. Impact of bovine oocyte maturation media on oocyte transcript levels, blastocyst development, cell number and apoptosis. Biol Reprod 2000;62:355-64.

30. Arcellana-Panlilio MY, Schultz GA. Analysis of messenger RNA. Meth Enzymol 1993;225:303-28.

31. De Sousa PA, Westhusin ME, Watson AJ. Analysis of variation in relative mRNA abundance for specific gene transcripts in single bovine oocytes and early embryos. Mol Reprod Dev 1998;49:119-30.

32. Chomczynski P, Sacchi N. Single-step method of RNA isolation by acid guanidinium thiocyanate-phenol-chloroform extraction. Anal Biochem 1987;162:156-9.

33. Downs SM, Daniel SA, Eppig JJ. Induction of maturation in cumulus cell-enclosed mouse oocytes by follicle-stimulating hormone and epidermal growth factor: evidence for a positive stimulus of somatic cell origin. J Exp Zool 1988;245:86-96.

34. Méduri G, Charnaux N, Driancourt M-A, Combettes L, Granet P, Vannier B, et al. Follicle-stimulating hormone receptors in oocytes? J Clin Endo Metabol 2002;87:2266-76.

35. Tilly JL, LaPolt PS, Hsueh AJ. Hormonal regulation of folliclestimulating hormone receptor messenger ribonucleic acid levels in cultured rat granulosa cells. Endocrinology 1992;130:1296-302.

36. LaPolt PS, Tilly J, Aihara T, Nishimori K, Hsueh AJW. Gonadotropininduced up- and down-regulation of ovarian follicle-stimulating hormone (FSH) receptor gene expression in immature rats: effects of pregnant mare's serum gonadotropin, human chorionic gonadotropin, and recombinant FSH. Endocrinology 1992;130:1289-95.

37. Chen L, Russell PT, Larsen WJ. Sequential effects of follicle-stimulating hormone and luteinizing hormone on mouse cumulus expansion in vitro. Biol Reprod 1994;51:290-5.

38. Eppig JJ, Wigglesworth K, Pendola F, Hirao Y. Murine oocytes suppress expression of luteinizing hormone receptor messenger ribonucleic acid by granulosa cells. Biol Reprod 1997;56:976-84.

39. Joyce IM, Pendola FL, O'Brien M, Eppig JJ. Regulation of prostaglandinendoperoxide synthase 2 messenger ribonucleic acid expression in mouse granulosa cells during ovulation. Endocrinol 2001;142:3187-97.

40. Tsai S-J, Wiltbank MC, Bodensteiner KJ. Distinct mechanisms regulate induction of messenger ribonucleic acid for prostaglandin (PG) $\mathrm{G} / \mathrm{H}$ synthase-2, PGE (EP3) receptor, and $\mathrm{PGF}_{2 \alpha}$ receptor in bovine preovulatory follicles. Endocrinology 1996;137:3348-55.

41. Sirois J. Induction of prostaglandin endoperoxide synthase-2 by human chorionic gonadotropin in bovine preovulatory follicles in vivo. Endocrinology 1994;135:841-8.

42. Narko K, Ritvos O, Ristimaki A. Induction of cyclooxygenase-2 and 
prostaglandin F2alpha receptor expression by interleukin-1beta in cultured human granulosa-luteal cells. Endocrinology 1997;138: $3638-44$.

43. Narko K, Saukkonen K, Ketola I, Butzow R, Heikinheimo M, Ristimaki A. Regulated expression of prostaglandin E(2) receptors EP2 and EP4 in human ovarian granulosa-luteal cells. J Clin Endocrinol Metab 2001;86:1765-8.

44. Johnson ML, Redmer DA, Reynolds LP, Grazul-Bilska AT. Expression of gap junctional proteins 43, 32 and 26 throughout follicular development and atresia in cows. Endocrine 1999;10:43-51.

45. Nuttinck F, Peynot N, Humblot P, Massip A, Dessy F, Flechon JE. Comparative immunohistochemical distribution of connexin 37 and connexin 43 during folliculogenesis in the bovine ovary. Mol Reprod Dev 2000;57:60-6.
46. Granot I, Bechor E, Barash A, Dekel N. Connexin43 in rat oocytes: developmental modulation of its phosphorylation. Biol Reprod 2002; 66:568-73.

47. Chen L, Wert SE, Hendrix EM, Russell PT, Cannon M, Larsen WJ. Hyaluronic acid synthesis and gap junction endocytosis are necessary for normal expansion of the cumulus mass. Mol Reprod Dev 1990;26:236-47.

48. Chen L, Mao SJT, Larsen WJ. Identification of a factor in fetal bovine serum that stabilizes the cumulus extracellular matrix. J Biol Chem 1992;267:12380-86.

49. Lazzari G, Wrenzycki C, Herrmann D, Duchi R, Kruip T, Niemann H, et al. Cellular and molecular deviations in bovine in vitro-produced embryos are related to the large offspring syndrome. Biol Reprod 2002;67:767-75. 